\title{
THE RELATIONSHIP BETWEEN STUDENTS' READING ATTITUDE WITH THE RESULT OF READING COMPREHENSION
}

\author{
${ }^{1,2}$ Muhammad Farhan Rafi, ${ }^{1}$ Aang Fatihul Islam, \& ${ }^{1}$ Dian Anik Cahyani \\ ${ }^{1}$ English Department, STKIP PGRI Jombang \\ ${ }^{2}$ Corresponding Author Email: m.farhan@stkipjb.ac.id
}

\begin{tabular}{|c|c|}
\hline Article Info & Abstract \\
\hline $\begin{array}{l}\text { Article History } \\
\text { Received: September } 2021 \\
\text { Revised: October } 2021 \\
\text { Published: October } 2021\end{array}$ & $\begin{array}{l}\text { Reading is a very important activity to get abundant information and add new } \\
\text { knowledge. As students, reading activities have a dominant role because they are } \\
\text { required to be more scientific and rational in giving opinions or providing oral } \\
\text { and written information. Besides, students' attitudes towards reading also have an }\end{array}$ \\
\hline $\begin{array}{l}\text { Keywords } \\
\text { Reading attitude; } \\
\text { Reading comprehension; }\end{array}$ & $\begin{array}{l}\text { important role. This study focused on students' reading comprehension and } \\
\text { attitudes towards reading in English. This study aims to determine whether there } \\
\text { is a significant relationship between students' attitudes with the result of reading } \\
\text { comprehension. Data was collected by distributing questionnaires and reading } \\
\text { comprehension tests for students of STKIP PGRI Jombang in the English } \\
\text { Education Study Program. The Pearson Coefficient Product Moment is used to } \\
\text { determine whether there is a significant relationship between students' attitudes } \\
\text { with the result of reading comprehension. The results found from the SPSS } 16 \\
\text { application with a sample of } 63 \text { students in the } 2019 \text { class show a correlation of } \\
0.478 \text {. This result indicates that students' reading attitudes are positively related } \\
\text { to their reading comprehension. Thus, students must continue to read to improve } \\
\text { their English reading skills. }\end{array}$ \\
\hline
\end{tabular}

How to cite: Rafi, M. F., Islam, A. F., \& Cahyani, D. A. (2021). The Relationship between Students' Reading Attitude with the Result of Reading Comprehension, JOLLT Journal of Languages and Language Teaching, 9(4) pp. 512-518. DOI: https://doi.org/10.33394/jollt.v\%vi\%i.4008

\section{INTRODUCTION}

One of the English skills that students of English education study programs must master is reading skills. As students, reading activities have a very dominant role because they are required to be more scientific and rational in giving opinions or providing information both in speech and writing. In addition, one of the activities that can improve student achievement is obtained from their reading ability because, by reading, students provide scientific answers to the questions given. The success of students in gaining scientific knowledge is obtained from a lot of reading. By reading, students can learn and get abundant information (Agustiani, 2017:75).

To get scientific information, reading comprehension is an activity that students must improve. According to Grabe and Stoller (2002), reading comprehension begins by knowing the basic purpose of reading and knowing supporting information from the reading topic through a complex process so that readers can understand the meaning of the text. In the article written by Agustiani (2017), there are several elements contained in reading comprehension, including the main topic, supporting information, vocabulary, references, implicit and explicit information, and organization in the text. So that in understanding a text, the process of reading and reading skills is a complex activity that must be conducted.

Besides reading comprehension, students' attitudes towards reading also have an important role. According to Pambuji (2015), several factors influence reading comprehension, namely interest, motivation, ability, and attitude. Therefore, in learning to read, of course, by 
paying attention to students' attitudes towards reading, it is an activity that can improve their understanding of the reading text.

Based on the information written above, this research was carried out in the secondsemester students of the English Education Department with the lesson of literal reading in the English Education Study Program STKIP PGRI Jombang. This course has two credits in one semester and is held for 16 meetings. Researchers researched with the aim of knowing the relationship between students' reading attitudes and reading comprehension so, whether it can be concluded that there is a significant relationship between students' reading attitudes and their learning achievement of literal reading.

\section{Reading Comprehension}

According to Samsu (2011), reading comprehension is a complex intellectual process that includes two main abilities: the ability to master meaning and think about verbal concepts. Turner in Dalman (2013) reveals that a reader is said to understand the reading well if the reader can: (1) recognize the words or sentences in the reading and know the meaning, (2) connect the meaning of the experience they have with the meaning in the reading text, (3) understand all meanings contextually, and (4) make judgments about the value of reading content based on the reading experience. Pearson and Johnson in Dalman (2013) state that reading comprehension is a reconstruction of the message contained in the text that is read so that there is an interaction of language and thought in the reading process. Alex in Ahmad (2000) states that reading comprehension is one of the reading strategies that aim to assess written work by involving oneself as well as possible in reading and making reliable analyses. Alex in Ahmad (2000) defines reading comprehension as a reading activity whose emphasis is no longer on letters or pronunciation and sentence understanding but on the ability to conclude the content of the reading. Sujanto in Oktaviani (2017) states that reading comprehension is an activity carried out by readers to connect new information with old information with the intention of gaining new knowledge. Based on some of the definitions above, it can simply be concluded that reading comprehension is a reading activity to understand the contents of the reading as a whole, both expressed and implied from the reading material.

Anderson in Dalman (2013) states that reading comprehension aims to understand the content of reading in the text. These objectives include: 1) to obtain details and facts, 2) to get the main idea, 3) to get the order of text organization, 4) to get a conclusion, 5) to get a classification, 6) to make comparisons or contradictions. 2 Based on the explanation Therefore, it can be concluded that the purpose of reading comprehension is to be able to capture messages, information, facts, or the main idea of reading well. More detailed reading comprehension is needed if we want to study and understand the problems we read into very detailed things.

\section{Attitude in Reading}

Scholl (2002: 2) defines an attitude as a human ability that influences a person's actions or behavior and feelings on certain entities, such as certain creatures, ideas, objects, or groups. Another understanding of attitude, according to Gregory (2004: 483) an attitude can be learned from cognitive, affective, or behavior to respond positively or negatively to certain objects, situations, institutions, concepts, or people. Attitudes have an evaluation and motivational component by helping a person to process perceptions and understand the world. From this statement, it can be concluded that attitude is a certain feeling that allows in influencing one's choices and perceptions of certain aspects in certain situations.

There are several theories defined by some experts about attitudes in reading. Matthewson's (2004) reading attitude affects the behaviors such as; intention to reading and sustain reading activity. These behaviors also affect reading, strategy use, text selection, attention and comprehension. Attitude in reading is an internal aspect that helps readers develop their reading skills. Yamashita (2004) explains that reading attitude is a statement about 
thoughts accompanied by feelings and emotions that make reading activities can be carried out. So, it can be concluded that attitude in reading is how a person evaluates or conducts a person towards all activities related to reading situations.

Attitude as a description of how someone understands an object or idea is an important factor in building a positive attitude. Kubiszyn \& Borich (1993: 171) stated that attitude measurement could help most teachers; 1. to identify students' understanding of reading activities in school, and can apply the best strategies in reading classes and to motivate students, 2. to assess the general changes that may occur in student attitudes, and 3. to determine the effect of student attitudes on the learning process. It can be concluded that the measurement of students' attitudes in reading has several important benefits for recognizing the application of attitudes themselves in reading activities and helping researchers to identify several factors that influence students' attitudes in reading.

The affective side of students is one of the biggest influences on the success or failure of language learning (Oxford, 1990: 140). He also added that the term affective refers to emotions, attitudes, motivations, and values (Oxford, 1990: 140). This statement becomes clearer when Wixon And Lipson, quoted in Kear \& Michael (2003), states that one of the factors that influence reading activities is reading's attitude. Students' own attitudes towards reading.

\section{RESEARCH METHOD}

This research method was employed in investigating a significant relationship between students' attitudes with the result of reading comprehension. The research method would state the research design, population and sample, instruments, and data analysis.

\section{Research Design}

This study aims to find out the relationship between students' reading attitudes and reading comprehension. Thus this study is designed as a correlation study. The correlation study includes research projects which attempt is to discover or clarify the relationship through the use of correlation coefficients (Latief, 2010). The correlation coefficient aims to express numerical terms in the degree of relationship between two variables (Latief, 2010). In addition, the relationship is perfectly positive if the correlation coefficient is 1.00 , but the relationship is perfectly negative if the correlation coefficient is -1.00 , and there is no relationship if the correlation coefficient is stated by 0 (zero). For collecting data, the researchers use research instruments, data analysis in quantitative or statistical design.

\section{Population and Sample}

This research was conducted at STKIP PGRI Jombang, especially in the English Education Study Program. In this research process, the population is all students of the English language study program. There are 294 students, while the sample is class A 2019 with 34 students and class B 2019 with 29 students using a purposive sampling system.

\section{Instruments}

The method of data collection in this study was the questionnaire and test methods as well as the research instrument. The questionnaire used is a questionnaire with 25 items about student attitudes towards reading activities adopted from Tullock-Rhody, Regina and Alexander, J.Estill. 1980 quoted from Agustiani (2017) and the test. The test used is a test designed with a reading ability test that is adjusted to the level of students' reading comprehension, which is validated by experts and tested first, and the results are tested validity and reliability.

\section{Data Analysis}

In the process of data analysis, there are two techniques, namely normality test and correlation test. A normality test is conducted to know whether the data of students' reading 
attitudes and the data of students reading ability are distributed normally. To do the normality test, the SPSS 16 application with a one-sample Kolmogorov-Smirnov Test is used. The correlation test is done to know the relationship between students' reading attitude and students reading ability. The SPSS 16 application is used to measure the relationship by using Pearson Product Moment Test. All data analysis techniques use the SPSS 16 application to help researchers find the results of the study that are in accordance with the objectives of this study.

\section{RESEARCH FINDINGS AND DISCUSSION Research Findings}

In this study, the data used is the value of the Rhody Secondary Reading Attitude Assessment questionnaire with a total of 25 statements and the value of the reading test taken from the Literal Reading course. The implementation of this research started from March to July 2020. The overall implementation of this research used online learning assisted by the Whatsapp and Google Classroom applications. This study applies an online method because conditions that do not allow face-to-face class are caused by the covid-19 outbreak. Questionnaire collection and student tests are carried out by answering the questionnaire at the address http://employee.heartland.edu/lcole/rhody/index.html while the test is carried out on the google form at the address https://bit.ly/Literal_Reading-Final_Test_2020. The results of the questionnaires and tests were calculated using SPSS 16 to determine the results of the normality test and the correlation test.

\section{Normality test}

The test was conducted to determine whether the data were normally distributed, both data on students' reading attitudes and data on students' reading comprehension. The results of the normality test show Asymp. Sig. (2-tailed) >0.05.

Table 1

Normality Test of Reading Ability data.

One-Sample Kolmogorov-Smirnov Test

Reading Comprehension

\begin{tabular}{llr}
\hline $\mathrm{N}$ & & 63 \\
\hline Normal & Mean & 73.37 \\
\cline { 2 - 3 } Parameters $^{\mathrm{a}}$ & $\begin{array}{l}\text { Std. } \\
\text { Deviation }\end{array}$ & 10515 \\
\hline Most Extreme & Absolute & .105 \\
\cline { 2 - 3 } Differences & Positive & .077 \\
\cline { 2 - 3 } & Negative &. .105 \\
\hline Kolmogorov-Smirnov Z & .835 \\
\hline Asymp. Sig. (2-tailed) & .488 \\
\hline a. Test distribution is Normal. &
\end{tabular}

Table 2

Normality Test of Reading Attitude data.

\begin{tabular}{|c|c|c|}
\hline \multicolumn{3}{|c|}{ One-Sample Kolmogorov-Smirnov Test } \\
\hline \multicolumn{3}{|c|}{ Student's Attitude } \\
\hline $\mathrm{N}$ & & 63 \\
\hline \multirow{2}{*}{$\begin{array}{l}\text { Normal } \\
\text { Parameters }\end{array}$} & Mean & 92.67 \\
\hline & $\begin{array}{l}\text { Std. } \\
\text { Deviation }\end{array}$ & 11335 \\
\hline
\end{tabular}




\begin{tabular}{llr}
\hline Most Extreme & Absolute & .110 \\
\cline { 2 - 3 } Differences & Positive & .057 \\
\cline { 2 - 3 } & Negative & -.110 \\
\hline Kolmogorov-Smirnov Z & .870 \\
\hline Asymp. Sig. (2-tailed) & .436 \\
\hline a. Test distribution is Normal. & \\
\hline
\end{tabular}

Based on the calculation results of SPSS 16 in Table 1 and table 2, it shows that Asymp. Sig $0.488>0.05$ and $0.436>0.05$. These results explain that the data on students' reading ability and reading attitudes are normally distributed.

\section{Correlation Test}

Based on the purpose of this study, namely to determine whether or not there is a positive relationship between students' reading attitudes and reading ability, the Pearson product moment correlation test was used.

Table 3

Correlation Test Results

\begin{tabular}{llrr}
\hline & \multicolumn{1}{c}{ Correlations } & & \\
\hline & & $\begin{array}{c}\text { Reading } \\
\text { Comprehension }\end{array}$ & $\begin{array}{c}\text { Student's } \\
\text { Attitude }\end{array}$ \\
\hline Reading Comprehension & Pearson Correlation & 1 & $.478^{* *}$ \\
\cline { 2 - 4 } & Sig. (2-tailed) & 63 & .000 \\
\cline { 2 - 4 } & $\mathrm{N}$ & $.478^{* *}$ & 63 \\
\hline Student's Attitude & Pearson Correlation & .000 & 1 \\
\cline { 2 - 4 } & Sig. (2-tailed) & 63 & 63 \\
\cline { 2 - 4 } & $\mathrm{N}$ & & \\
\end{tabular}

\begin{tabular}{|c|c|c|c|}
\hline \multicolumn{4}{|c|}{ Correlations } \\
\hline & & $\begin{array}{c}\text { Reading } \\
\text { Comprehension }\end{array}$ & $\begin{array}{l}\text { Student's } \\
\text { Attitude }\end{array}$ \\
\hline \multirow[t]{3}{*}{ Reading Comprehension } & Pearson Correlation & 1 & $.478^{* *}$ \\
\hline & Sig. (2-tailed) & & .000 \\
\hline & $\mathrm{N}$ & 63 & 63 \\
\hline \multirow[t]{3}{*}{ Student's Attitude } & Pearson Correlation & $.478^{* *}$ & 1 \\
\hline & Sig. (2-tailed) & .000 & \\
\hline & $\mathrm{N}$ & 63 & 63 \\
\hline
\end{tabular}

**. Correlation is significant at the 0.01 level (2-tailed).

Looking at the results in table 3, it can be seen that the coefficient value of the relationship between students' reading attitudes and reading ability is 0.478 , with a significant value of 0.000 . Based on these results, the significance value is less than $0.05(0.000<0.05)$, then the results of this study can be said that the relationship between the two variables, namely students' reading attitudes and reading skills, is significant with a correlation value of 0.478 . With this value, the relationship between the two variables is said to be positive in the medium category. 


\section{Discussion}

The results of the findings of this study can be said that there is a positive relationship between students' reading attitudes and their reading ability. Related to the result of this study, it shows that reading comprehension from students about the main topic, supporting information, vocabulary, references, implicit and explicit information, and organization in the text can improve better when they implicate the reading attitude. The result of this study supported the study of Pambuji (2015) that reading attitude influences students' reading comprehension. In addition, According to Kear \& Michael (2003), one of the factors that influence reading activities is the student's own attitude towards reading. Meanwhile, the findings stated that the positive relationship in the medium category showed that students who had good reading attitudes did not necessarily get good scores on reading skills, but students who got good marks on reading skills certainly had good reading attitudes. According to Oxford (1990), students' attitudes towards the learning process are one of the biggest influences on the success or failure of language learning.

The result of this research shows that students' attitude relates to students' reading comprehension. Students really can know what to read because they can find what they like in reading. This result is also related to Matthewson's (2004) reading attitude affects behaviors such as; intention to reading and sustain reading activity. These behaviors also affect reading, strategy use, text selection, attention, and comprehension. The result also stated that students' attitudes could develop reading skills. In addition, attitude in reading is an internal aspect that helps students develop reading skills. Students can develop reading skills because their feeling or emotion about reading bring them to good condition while reading. Yamashita (2004) explains that reading attitude is about thoughts accompanied by feelings and emotions that can implement reading activities.

\section{CONCLUSION}

Based on the results of the study, it can be concluded that students' reading attitudes are positively related to reading skills even though the significance level is still in the moderate category. These results indicate that students' reading attitudes are one of the fundamental factors that influence the success or failure of the learning process on reading skills (Oxford, 1990). Reading attitudes can be maximized depending on the needs, development of language skills, environment, and student situation. In addition, students must have good English skills, especially in reading comprehension. Students' reading skills can develop better if they are serious about continuing to develop their English language skills by improving their learning and practice methods.

\section{ACKNOWLEDGEMENT}

The researchers would like to thank STKIP PGRI Jombang that has supported the whole process of the research. The researcher sends big thanks to English Education Department at STKIP PGRI Jombang. This research cannot be conducted very well without any help from you. Special thanks to students of 2019 A and 2019 B who have a very good attitude because they have helped the researchers to conduct the research. 


\section{REFERENCES}

Agustiani, IWD. (2017). The Correlation between Students' Reading Attitude and Their Reading Comprehension Achievement. English Community Journal. 1(2): 75-85

Dalman. (2013). Reading Ability. Jakarta: Rajawali Press

Gregory, R J. (2004). Psychological testing: history, principles, and application. (4th ed.). International Student Edition. New York, NY: Pearson Education Group

Harjasujana, A. S. (2000). Reading Skills. Jakarta: Karunika Jakarta.

Kubiszyn, T., \& Borich, G. (1993). Educational testing and measurement: classroom application and practice. (4thed.). New York, NY: Harper Collin College Publisher

Mathewson, G.C. (2004). Model of Attitude Influence Upon Reading and Learning to Read. In R. B. Ruddel \& N. J. Unrau (Eds.), Theoretical Models and Processes of Reading (Vol. II, pp. 1431- 1461). Newark,USA: International Reading Association.

Latief, M.A. 2010. Tanya Jawab Metode Penelitian Bahasa. Malang: UM Press.

Oktaviani, ME (2017). The Correlation of Reading Interest Against Reading Comprehension in Indonesian Language Subjects for Class Vimin 1 South Lampung School Year 2017/2018. Thesis. Faculty of Tarbiyah and Teacher Training, Raden Intan State Islamic University, Lampung.

Oxford, RL (1990). Language learning strategies : What every teacher should know. Boston, MA: Heinle and Heinle Publishers.

Pambuji. A. (2015). The Correlation among Attitude, Reading Comprehension, and Writing Achievement of English Education Study Program Students Of Sriwijaya University. Administrative Journal. 1 (1): $17-28$

Samsu, S. (2011). Strategies and Techniques for Learning to Read. Yogyakarta: Graha Ilmu..

Scholl, RW. (2002). Attitudes and attitudes change. Journal of Classification, 3, 1 - 35.

Sugiyono. (2011). Quantitative, Qualitative, and R\&D Research Methods. Bandung: Alphabeta $\mathrm{CV}$

Yamashinta, J. (2004). Reading attitudes in L1 and L2, and their influence on L2. extensive reading. Journal of Reading in Foreign Languages. 